DOI: 10.32370/IA_2021_06_11

\title{
Establishment of Eastern European Theater Pantomyms
}

\author{
Svarnyk Bohdan \\ lecturer, \\ Kiev National University of Culture and Arts, \\ Kiev, Ukraine
}

\begin{abstract}
The features of the origin and development of the pantomime theater in the countries of Eastern Europe in the 60-70s of the XX century are studied on the basis of the analysis of the experimental activities of the founder of the Czech school of classical modern pantomime L. Vialka, the Slovak pantomime M. Sladek, the Latvian artist, actor and director M. Tenisson, Estonian pantomime by A. Traks. The study found that pantomime became widely popular in a number of European and post-Soviet countries in the second half of the twentieth century, but it is a borrowed form because there are similar elements between ancient traditional pantomime productions and some of its European varieties. Borrowing cultural institutions or their individual components is possible only if the host culture has certain favorable conditions for their assimilation. At the same time, the borrowed material noticeably changes in the process of the influence of a whole complex of historical, social, religious and cultural factors, which determine the philosophical and aesthetic specifics of the new phenomenon. phenomenon.

Key words: pantomime, pantomime culture, pantomime theater, mime, plastic culture, cultural
\end{abstract}

Постановка проблеми. Пантоміма, як самостійний вид сценічного мистецтва, джерелом якого $є$ ритуальні дійства, сформувалася внаслідок художнього розвитку театральної практики в контексті специфіки соціокультурного простору античного суспільства.

Наприкінці V ст. після падіння Римської імперії, розпаду рабовласницького та заснування феодального суспільства, починає формуватися новий театр, а відповідно й нові сценічні форми, проте його джерелами безумовно лишалася антична культура. В середині XVI ст. завдяки виникненню італійської комедії дель арте в західноєвропейських країнах формуються стійкі традиції пантомімічних вистав, що зберегли власну специфіку і на сучасному етапі.

Вагомий внесок у подальше еволюціонування мистецтва пантоміми здійснив Ж.Г. Дебюро (провідний французький актор XIX ст.), творчість якого зумовила розвиток поетичної пантоміми як окремого жанру та Е. Декру в 30-ті pp. XX ст., діяльність якого посприяла переосмисленню мистецтва пантоміми у сучасному контексті. Проте відродження театру пантоміми безпосередньо пов'язано з діяльністю експериментальних 
творчих колективів Східної Свропи другої половини 1950-х - 1960-х рр., що і досі лишається недостатньо висвітленою у вітчизняному науковому вимірі.

Аналіз останніх досліджень і публікацій засвідчує наявність багатьох грунтовних досліджень та розвідок, в яких культура пантоміми розглядається та аналізується в багатьох аспектах з культурологічних, мистецтвознавчих та театрознавчих позицій. Більшість з них належать закордонним дослідникам - А. Банаху («Генріх Томашевський грає 3 міфом») [6], Е. Клівісу («Есcе homo: динаміка репрезентацій людини в Литовському радянському театрі») [10], А. Константиновій («Від людини до людини. Модріс Тенісон та п’ять років Каунаській студії пантоміми») [1], К. Топферу («Пантоміма: історія та метаморфози театральної ідеології») [14], та ін. і присвячені висвітленню окремих аспектів означеного питання або дослідженню творчості конкретного представника пантомімічного мистецтва.

Особливості становлення театру пантоміми в країнах Східної Європи другої половини XX ст. як цілісного явища не стали предметом самостійного наукового дослідження, а наявна інформація потребує доповнення та переосмислення з позицій сучасної культурології.

Мета статті - виявити особливості зародження та розвитку театру пантоміми в країнах Східної Свропи.

Ранніми проявами пантоміми в країнах східної Свропи, що були зумовлені «відлигою» в галузі культури з боку комуністичної партії стали експерименти кількох польських студентських груп в Гданську, які спеціалізувалися на візуальному театрі в 1954-1956 pр. (хоча безпосередньо пантоміму артисти не використовували), діяльність студії пантоміми X. Томашевського у Вроцлаві (Польща) та Ризької компанії пантоміми Р. Лігера в Латвії (обидві засновано у 1956 р.), а подальший розвиток мистецтва пантоміми найбільше проявився у творчості представників Германської Демократичної Республіки, Чехословаччини, Угорщини, Естонії, Литви та Болгарії. Водночас дослідники наголошують, що не зважаючи на те, що сигналом до дозволу на публічне виконання пантоміми від провладних інституцій стали виступи М. Марсо, ані Г. Томашевський, ані Р. Лігер не вважали його естетичну модель взірцем для себе [14, p. 76]. Наприклад, К. Топфер стверджує, що деякі країни Східного блоку схвалили клоунську парадигму пантоміми. Наприклад, у Чехословаччині культура пантоміми часів 
холодної війни зародилася довкола постаті Л. Фіалки (1931-1991рр.) - основоположника чехословацької школи класичної сучасної пантоміми, який створив клоунські образи за взірцем М. Марсо, П'єро і своєрідну фігуру Ч. Чапліна з білим обличчям, в краватціметелику і солом'яному капелюсі. Він вивчав хореографію в Празькій консерваторії тацю, а в 1953-1954 рр. ставив пантомімічні танці за казками П’єро у виконанні Ж.-Г. Дебюро. Після зустрічі у Парижі в 1956 р. з М. Марсо, Л. Фіалка вирішує створити власну трупу пантоміми, що вдалося реалізувати зі студентами консерваторії I. Вискочилом, I. Сухі та В. Вассерманом у 1958 р. Театр пантоміми «Дивадло на Забрадлі» невдовзі став всесвітньо відомим. Перші постановки трупи відбулися за рік у приміщенні Театру Балюстради - передусім це були шоу пантоміми-ревю / кабаре, в яких дія відбувалася довкола персонажів-клоунів [14, p. 89].

Постановки «Пантоміма на Забрадлі» (1959 р.), «Дев’ять капелюхів над Прагою» (1960 р.), «Етюди» (1960р.) та «Дорога» (1962р.) тяжіють до взірців французької пантоміми М. Марсо та Е. Ж. Далькроза, хоча, на думку мистецтвознавців, у репертуарі театру поступово з'являються нові трактування широко відомих пантомім Ж.-Л. Барро «Кінь», М. Марсо «Стильові вправи», «Юність, Зрілість, Старість, Смерть» та ін., Ж. Сегаля «Півні», «Історія капелюхів» - оригінальні мініатюри «Каріатіди», «Життя стоячи», «Шахи» та ін. [3].

У 1964 р. він здійснив постановку хореографії пантомімічних дій у вибуховій, орієнтованій на клоуна постановці Я. Гросмана за п’єсою А. Джаррі «Король Убу», в якій здійснив спробу увести пантоміму від впливу М. Марсо в бік ідей А. Арто, хоча вона все ще була своєрідним «безумним клоунським шоу» [11, р. 105]. Власне художнє кредо Л. Фіалко, мистецтво якого вирізнялося досконалістю жестикуляцій та міміки, ліризмом та елементами гротеску, представив у творі «Блаженні» в 1965 р.

Дослідники припускають, що Л. Фіалка прагнув відродити комічні розваги в стилі кабаре у виконанні клоунського дуету Г. Восковца (1905-1981 рр.) та Я. Веріха (19051980 рр.), які надзвичайно успішно проходили в Празі в 1930-х рр., трансформувавши виступи, що складалися переважно з лівої політичної сатири, дотепних жартів і жартівливих пісень, доповнених танцювальними номерами відповідно власного бачення. Замість політичної сатири Л. Фіалка активно інтегрував у пантоміму елементи 
абсурдизму, полюбляв драматичні твори С. Бекета. У 1970-х рр. його шоу стали більш поетичними, втім не позбавленими комізму [14, p. 98].

Цікавим прикладом є постановка «Колаж» 3 шести сцен «Капрічос» (1971р.), постановку якої було здійснено під впливом сатирично-гротескних малюнків іспанського живописця і гравера Ф. Гоя, на яких було карикатурно зображено розкладання католицької церкви та «Фунабули» (1977р.) - сцени з життя Ж.-Г. Дебюро. У 1980-х рр. трупа розробила клоунські номери, натхненні творами М. Гоголя, фільмами Ф. Фелліні та образами снів художників І. Трнка та Я. Прейслера [9, р. 72-74].

Натомість Словацька пантоміма М. Сладека не мала міцних зв’язків зі стилем пантоміми Декру-Марсо. Азом 3 Е. Злабеком, танцюристом Театру Буріана, він сформував ансамбль пантоміми в 1960 р., створивши образ П’єро, Кефку, клоуна з білим обличчям, який носить різноманітні чудернацькі костюми. У 1962 р. його ансамбль «Кефка» став частиною Словацького національного театру, розпочавши постановки пантомімічних версій відомих драм, біблейських казок та опер. Прагненню відкрити театр з пантомімою, кабаре та п’єсами завадило вторгнення в Чехословаччину радянських військ - М. Сладек втік до Швеції, а згодом до Німеччини, де в 1970 р. заснував у Кельні Театр пантоміми Кефки, розпочавши популярні серії пантомімічних адаптацій відомих літературних творів: «Подарунок» (1971р.), «Дон Хуан» (1978 р.), «Кармен» (1983 р.) та ін., що стали невдовзі широковідомі міжнародній аудиторії.

В Прибалтиці спроби застосування досвіду М. Марсо надзвичайно сильно тяжіли до інтегрування його в європейську студійну традицію, зокрема до паратеатральних форм. На думку дослідників, це пояснювалося тим, що західноєвропейська академічна театральна школа не була домінантним явищем у порівнянні з радянською, що отримала у спадок теорію і практику найбільшої кількості творців режисерських систем початку XX ст. А. Константинова стверджує, що найбільш пріоритетна для «радянської Європи», тенденція вільного самовираження за умови лояльного ставлення до подробиць форми у поєднанні з ренесансом прибалтійської національної самосвідомості та загострення конфлікту поколінь отримала специфічне вираження в литовському театральному мистецтві загалом та пантомімі зокрема [1, с. 54].

Е. Клівіс, досліджуючи образи людей в литовському театрі за радянських часів, акцентує на трансформаціях в техніках репрезентації та змінах в ідентичності 
радянського суспільства, а також моральних та ідеологічних змінах про які вони свідчать. Науковець виділяє три стадії - метонімію емоцій, моральні алегорії та метафори внутрішнього простору, що, на його думку, окреслюють зміни в бік створення образів субстантивної психіки людини за рахунок витиснення конкретної історичної реальності i водночас тісно пов'язані 3 поступовим переходом від акторського театру до режисерського [10, p. 196].

Разом із акторськими прийомами психологічної метонімії в другій половині 1970x pp. почали кристалізуватися форми режисури та пов’язане 3 ним розмаїття репрезентації людини.

Першими варіантами форм, що розкривають деякі важливі трансформації людського образу, стали пантоміми М. Тенісона, латвійського художника, актора i режисера, який закінчивши школу прикладного мистецтва в Ризі навчався і працював у самодіяльному театрі «Ригас пантоміма», заснованого в 1956 р. завдяки ініціативі актора театру «Дайлес» Р. Лігерса.

У 1966 р. М. Тенісон зібрав першу в Литві трупу пантоміми, що складалася 3 дев'яти ентузіастів жанру - Г. Мацкявічюс, Е. С. Паулюконіс, З. Банявічюс, Е. Савіцкіс, Е. Савукінайте, Я. Мікшите, В. Петрушкявічюс, В. Мартиновас (дев'ятий - сам М. Тенісон) та здійснив постановку першої вистави на базі Молодіжного театру. Репетиції трупи з першого дня нагадували невеликі вистави, розповіді в метафоричних формах новаторськими та актуальними [5, p. 89].

Алегорично-пластичний, узагальнений образ людини М. Тенісон репрезентує в першій виставі «Ессе Ното», постановку якої було здійснено в 1967 р. У програмі постановки вказувалося, що «це цілісна поетична казка про Людину. Людину та світ, боротьбу людини з долею, їі супротив грубій силі, інстинктам темного натовпу, брехні та лицемірству, про їі нескінченну боротьбу за світло» [8, с. 43]. Трупа обрала напрям «нової пантоміми, рухаючись від mime pur (Марсель Марсо) та більш літературної пантоміми (Московський театр міміки та жестів) до синтетичної під впливом Ет'єна Декру» [8, p. 43].

Відповідно задуму постановника, перша частина вистави - своєрідне введення в мистецтво пантоміми, що знайомить глядача з його класичними елементами, а друга плід оригінальної роботи, що відкривала напрямок творчого пошуку трупи, метою якої 
було не соло, а колективна пантоміма. Отримавши надзвичайно позитивні відгуки театральних критиків, теоретиків і практиків театру, а головне - сприйняття глядачів, трупа була змушена покинути Молодіжний театр, оскільки невдовзі після прем'єри виявилося, що «учасники цієї вистави Молодіжного театру насправді є учасниками нового творчого колективу, чужорідним тілом драматичної трупи» [12, p. 65]. Не зважаючи на те, що Міністерство культури та Рада міністрів погодилися на виділення трупі пантоміми спеціальних коштів в складі трупи молодіжного театру, дирекція та адміністрація театру категорично відмовилися від приходу молоді у структуру театру. Влітку 1967 р. М. Тенісон зі своєю трупою приєдналися до трупи Каунаського драматичного театру, яскраво зігравши у виставі «Полювання на мамонта» за п'єсою Казіса Сая (режисер Й. Юрашас, 1968 р.), а також у власних пантомімічних виставах М. Тенісона «Сни снів» (1968р.) - тричастинна постановка, що складалася з прологу, «Фуги» (побудована на основі думок, настроїв та асоціація, викликаних музикою та живописом литовського художника і композитора М. Чюрленіса) та «Метаморфоз» (мініатюри «Так загинуло місто Помпеї» - «гротеск, де комічне щільно підведено до трагедії і переростає в неї» [4], «Безособовість» та «Маленькі долі» - «фантастичні та феєричні вистави») [4]; казкова вистава для дітей «Бережіть метелика!» (1969 р.) «про злу відьму, про іiі вірного слугу - ворона, про сім добрих гномів» [2, с. 3].

На думку дослідників більшість вистав Каунаської пантоміми вирізнялися специфічною побудовою: змонтовані 3 «філософських етюдів», алегорій, емблем та знаків - режисер намагався розробляти цей прийом, вдосконалюючи вже винайдене, виявляючи в ньому нові грані та фарби [1, с. 63]. Наприклад, в тричастинну виставу «Сни снів» увійшла композиція «Про те, що могло б бути...» 3 вистави «Ессе Ното». А. Константинова стверджує, що особливої привабливості виставам надавав типовий для М. Тенісона композиційний прийом, коли персонажі в межах одного сюжету кілька разів «переміщувалися» 3 максимально умовного поетичного простору в «більш або менш реальний» - і навпаки. Дослідниця наголошує, що саме в цих переходах від абстрактної пластики до іï «олюдненого» прояву унаочнювалося відчуття трагізму життя, що так властиве найвищим взірцям мистецтва пантоміми, наділених, за Е. Декру, невід'ємним «правом на нещастя» [1, с. 61]. 
Для вирішення проблеми драматургії пластичного театру М. Тенісон обрав три паралельно освоювані шляхи: вибір джерела в галузі образотворчого мистецтва, що передбачало асоціативно-поетичне сценічне трактування; виховання актора-співавтора, який здатний здійснити таке трактування, відчуваючи композицію ансамблю та може імпровізаційно в неї інтегруватися; винайдення оригінальної мови вираження художнього образу.

Е. Савукінайте наголошує, що семантика постановки була організована М. Тенісом довколо трьох ключових символів: творець-творчість; маса-міщанство; диктатор-фашизм - дія вистави рухалася потиборництвом та взаємовпливом цих силсимволів [13, p. 147]. Пластичні образи вистави, відповідно задуму режисера, мали бути максимально стилізовані та виразні.

У серпні 1970 р. трупа пантоміми була переведена в Каунаський музичний театр, а в 1971 р. було здійснено постановку вистави «Колаж» (1971р.), сповнену пошуків режисера, незмінно звернених «від людини до людини... в усі часи та сьогодні» $[14$, p. 23].

Тематична спрямованість, що виділяла не історичне, а особистісне-індивідуальне та підкреслювала його незворотність та нескінченний конфлікт 3 «темним натовпом і машиною насилля» в першій виставі трупи було побудовано як редагування коротких оповідань та пізніше повторене (з більш складними техніками, візуальною структурою та включенням у виконання різних фактів візуальної культури, починаючи з творів X. Боша та Ф. Гойї та закінчуючи колажами з документальних фотографій) у трьох інших постановках трупи. Мобілізовані візуальні рішення, спровоковані не драматургічними текстами, а досвідом художника-графіка М. Тенісона, цитати з творів мистецтва, виразні мізансцени. Усі постановки режисера, починаючи від «Есcе Ното» i закінчуючи «Kolažas» (прем’єра в 1971 р.) були пов’язані єдиним символічним наративом, віссю якого, по суті, є моральний конфлікт між абстрактною особистістю (безіменний сучасник глядача, Людина) та негативні, інертні і анонімні натовпи (роботи, маски, протигази, безликі городяни та ін.). Зіткнувшись 3 Анонімним Натовпом, Людина має дві можливості: піддатися їх впливу і стати маріонеткою, засудивши себе на безплідне існування, або не пристосовуватися, бунтувати i, зрештою, загинути. 
Керуючись у власних інтуїтивно-образотворчих пошуках синтетичними досвідами М. Чюрленіса, стильовими прийомами М. Марсо, графічною пластикою вистав Г. Томашевського та радикальними експериментами Є. Гротовського, М. Тенісон осмислював дієву природу мистецтва пантоміми через виявлення загального в природі пластичних мистецтв, кожне з яких є способом образної візуальної уваги глядача.

Порівняно скромна культура пантоміми в Естонії сформувалася у другій половині ХХ ст. довкола персони А. Тракса, який заснував у 1963 р. Молодіжну студію пантоміми при Талліннському Палаці культури. Не наголошуючи на впливі естетики ризької трупи пантоміми та експериментах А. Бахмана в Талліннському театру (Tallinn Hommikteater) 1920-х pp., А. Тракс створював власну, акцентуючи на дисциплінованості та «відкритості» пантоміми, як унікального виду «гармонії». Перші виступи Студії навеснівлітку 1965 р. - програма «Тиха година», що складалася з невеликих ансамблевих замальовок або «мініатюр» («Обережно», «Приятелі в походах», «Наступає осінь», «Романтика», «Початок і кінець місяця» та ін.) відбувалися на сцені Талліннського палацу культури, розвалинах Домініканського монастиря в Старому місті. В одній 3 абстрактних постановок виконавці були вдягнуті в фосфоруючі рукавички, комірці і чорні боді, відповідно глядач бачив лише рухи освітлених об'єктів (запозичивши латиські костюми, А. Тракс не використовував «біле обличчя», оскільки, на його думку, воно заперечувало індивідуальність виконавця).

В 1967 р. ансамбль здійснив постановку програми мініатюр «Диво без див», що складалася з трьох частин: «Арлекіно» - мініатюра, вирішена в стилістиці комеді дель арте, в якій виконавці були вдягнуті в традиційні для цього жанру костюми і зображували основних фігур - Арлекіно, Панталоне, Коломбіну, П’єро та Бріганте; у другій частині було представлено номери з дивовижного цирку, зокрема «Найсильніша в світі жінка», «Танцюристка на мотузці», «Руда», «Чарівник», «Двоголове теля», «Змія та Білий клоун» («Заклинатель змій» та ін.; третій розділ включав серйозні сцени: «Імперіалізм», «Людина і машина», «Еволюція» (в мініатюрі зображувалося космічне походження життя, починаючи від застигання пилу до утворення організмів, появи людей, створення рабства і цивілізації та зрештою революційного звільнення людства).

Невдовзі через конфлікт між А. Траксом та керівництвом Академічного драматичного театру колектив Студії було розпущено. Мистецтвознавці припускають, 
що основою конфлікту стало використання у пантомімічних постановках музики композиторів, які критикувалися або взагалі не рекомендувалися в Радянському Союзі [14, p. 93]. У 1970-1977 pр. А. Тракс повернувся на посаду директора Філармонії та сформував новий ансамбль «Талліннська пантоміма» зі студентів столичних районних будинків культури. Для досягнення «психофізичного» вираження А. Траксом було розроблено власні вправи та «творчі ігри», з метою розвитку у акторів передусім швидкості та точності, наприклад, «Машина» (метою вправ було досягнення машинної точності, незалежно від швидкості), «Скульптура» (відомий акторський етюд, в якому треба зупинитися у певній позі та втримати іiі) X. Ейнасто (член трупи, згодом відомий естонський хореолог) згадує, що педагогічне середовище створене А. Траксом чимось нагадувало підхід Е. Декру. Керівник заохочував різкий, кутовий, рушійний стиль пантомімічного руху: «Усі плавні лінії та потоки були порушені та розбиті на шматки» $[7$, p. 4].

Перша постановка «Талліннської пантоміми» «Контрасти» (1979 р.) складалася 3 серії ранніх мініатюр, відроджених режисером, проте в наступних постановках, що класифікувалися А. Траксом як драми, трагікомедії або трагедії, були побудовані як ціннісна розповідь.

Не зважаючи на грандіозну універсальність тем, пантомімічні постановки А. Тракса не досягли рівня сценічних творів М. Тенісона, Г. Томашевського та Г. Мацкявічюса. На думку дослідників, це пояснювалося не лише тим, що режисер не мав доступ до театральних ресурсів, а й тим, що йому не вистачало містичного уявлення про тіло як про символ, що недоступне для держави та загальноприйнятої моралі [14, p. 99]. Пантоміма за А. Траксом була шляхом до нового суспільства, заснованого на індивідуальній моралі, що виникає в результаті відновлення душі, совісті, що були в «диханні» тілесного руху, а не у вербальних засобах виразності, що завуальовують уявлення про тіло та душу.

Висновки. Театр пантоміми, що отримав значне поширення в країнах Східної Свропи в другій половин XX ст. має давньогрецьке походження. Незважаючи на те, що конкретне джерело запозичення однозначно визначити неможливо, між античною, середньовічною та сучасною традиціями пантомімічних вистав наявні глибинні родинні зв’язки, що пояснюються особливостями пантомімічного мистецтва як особливого типу 
видовищ. Дослідження виявило, що запозичення театру пантоміми як культурного інституту або його окремих складових стало можливим завдяки створенню сприятливих умов для їх асиміляції. При цьому запозичений з античної та середньовічної пантоміми матеріал помітно видозмінювався, в процесі впливу цілого комплексу історичних, соціальних, релігійних та культурних факторів, що і визначили філософську та естетичну специфіку східноєвропейського театру пантоміми другої половини XX ст. як нового явища.

\section{References}

1. Konstantinova, A. V. (2013). From person to person. Modris Tenison and Five Years of the Kaunas Pantomime Studio. Theatron, no. 1 (11), pp. 53-71.

2. Krugovykh, A. (1971). The language of silence. Lenin sparks. 22 Sep p. 3.

3. Markova, E. (1974) Pantomimes of Ladislav Violet. Theatre, no. 4, pp. 130-132.

4. Yurna, T. (1968). The exam passed. Komsomolskaya Pravda. Vilnius. May 15.

5. Armonaite, L. (sud.). (2018). Giedrius Mackevičius (1945-2008) ir jo Teatras : teatro novatorius, sukūręs plastinės dramos žanrą. Vilnius : Lietuvos teatro, muzikos ir kino muziejus.

6. Banach, A. (2019). Henryka Tomaszewskiego gra z mitem.

7. Einasto, H. (2002). Unpublished conference paper about studying pantomime with Adolf Traks presented at IFTR/FIRT Amsterdam conference Choreography and Corporeality working group.

8. Gudelis, A. (1968). Gera pradpia. O kas toliau? Kultûros barai, no. 10, pp. 43-46.

9. Holeňová, J. (ed.). (2001). Český taneční slovník: tanec, balet, pantomime. Praha: Divadelní ústav.

10. Klivis, E. (2005). Ecce homo: pmogaus reprezentacijø dinamika lietuvos sovietmeèio teatre. Logos, no 43, pp. 196-207.

11. Miholová, K. (2007). Král Ubu-Jarry \& Grossman \& Fára-Divadlo Na zábradlí 1964-1968, Prague: Kant.

12. Ragauskaitè, A. (2000). Režisierès užrašai.

13. Savukynaite, E. (2001). Lietuvos pantomime 1967-1972 metais. Klaipėdos.

14. Toepfer, K. (2017). Pantomime: The History and Metamorphosis of a Theatrical Ideology. Vosuri Media San Francisco.

\section{Translation of the References to the Author's Language}

\section{Список використаних джерел}

1. Константинова, А. В. (2013). От челове к человеку. Модрис Тенисон и пять лет Каунасской студии пантомимы. Театрон. № 1(11). С. 53-71. 
2. Круговых, А. (1971). Язык молчания. Ленинские искры. 22 сент. С. 3.

3. Маркова, Е. (1974) Пантомимы Ладислава Фиалки. Театр. № 4. С. 130-132.

4. Юрна, Т. (1968). Экзамен выдержан. Комсомольская правда. Вильнюс. 15 мая.

5. Armonaitè, L. (sud.). (2018). Giedrius Mackevičius (1945-2008) ir jo Teatras : teatro novatorius, sukūręs plastinès dramos žanrą. Vilnius : Lietuvos teatro, muzikos ir kino muziejus.

6. Banach, A. (2019). Henryka Tomaszewskiego gra z mitem.

7. Einasto, H. (2002). Unpublished conference paper about studying pantomime with Adolf Traks presented at IFTR/FIRT Amsterdam conference Choreography and Corporeality working group.

8. Gudelis, A. (1968). Gera pradpia. O kas toliau? Kultûros barai. Nr. 10. pp. 43-46.

9. Holeňová, J. (ed.). (2001). Český taneční slovník: tanec, balet, pantomime. Praha: Divadelní ústav.

10. Klivis, E. (2005). Ecce homo: pmogaus reprezentacijø dinamika lietuvos sovietmeèio teatre. Logos. № 43. C. 196-207.

11. Miholová, K. (2007). Král Ubu-Jarry \& Grossman \& Fára-Divadlo Na zábradlí 1964-1968, Prague: Kant.

12. Ragauskaitė, A. (2000). Režisierès užrašai.

13. Savukynaite, E. (2001). Lietuvos pantomime 1967-1972 metais. Klaipėdos.

14. Toepfer, K. (2017). Pantomime: The History and Metamorphosis of a Theatrical Ideology. Vosuri Media San Francisco. 